\title{
Granulocyte and HLA-D region specific monoclonal antibodies in the diagnosis of Hodgkin's disease
}

\author{
AJ NORTON, PG ISAACSON
}

From the Department of Histopathology, Medical School, University College, London

SUMmaRy Tissue sections embedded in paraffin and fixed in formalin from 32 patients with Hodgkin's disease, representing the major histological subtypes, were studied using two granulocyte specific monoclonal antibodies (Leu-M1 and 3C4) and an HLA-D region specific monoclonal antibody (TAL-IB5). Reed-Sternberg cells were stained with one or other of the antigranulocyte antibodies in the nodular sclerosing and lymphocyte depleted subtypes. ReedSternberg cells in all but three cases of mixed cellularity Hodgkin's disease were positive with both Leu-M1 and 3C4. One case stained with only Leu-M1, and two cases were consistently negative with both antibodies. HLA-DR was widely expressed in the Reed-Sternberg cells of all three subtypes. In the four cases of lymphocyte predominant Hodgkin's disease the multinucleated Reed-Sternberg cells did not stain with either antigranulocyte antibody but were strongly positive with anti-HLA-DR. Twenty five cases of non-Hodgkin's lymphoma, in which there were multinucleated giant cells resembling Reed-Sternberg cells, were studied in a similar way. These cases included pleomorphic T cell and B cell lymphomas, histiocytic lymphomas, and malignant histiocytosis of the intestine. In none of these did the multinucleated cells stain with either antigranulocyte antibody, but in most cases the multinucleated cells stained with anti-HLA-DR. In two cases of the tumour stage of mycosis fungoides dot like intracytoplasmic staining was shown in the tumour cells with both antigranulocyte markers. The monoclonal antigranulocyte antibodies Leu-M1 and 3C4 are of considerable value in both the diagnosis and the differential diagnosis of Hodgkin's disease and are particularly valuable in that they can be applied to tissue fixed in formalin and embedded in paraffin. Antibody to HLA-DR, while useful, is of less value.

The histological diagnosis of Hodgkin's disease may not always be straightforward. The classical cellular subtypes may be mimicked by reactive lymphoid proliferations ${ }^{12}$ and the non-Hodgkin's lymphomas. The presence of cells similar to Reed-Sternberg cells has been described in a variety of epithelial and lymphoid tumours. ${ }^{3}$ Notably, $T$ cell lymphomas may have a reactive cellular infiltrate of lymphocytes, eosinophils, and plasma cells, together with cells like Reed-Sternberg cells, ${ }^{45}$ so as to be almost indistinguishable from Hodgkin's disease. Pleomorphic B cell lymphomas of follicle centre cell derivation may also contain polylobated and giant cells resembling Reed-Sternberg cells. ${ }^{6}$ Histiocytic lymphomas and cells of malignant histiocytosis of the intestine have also been observed to resemble Reed-Sternberg cells in Hodgkin's disease.

Several monoclonal antibodies have been shown to be of value in staining Reed-Sternberg cells

Accepted for publication 25 July 1985 and their mononuclear counterparts. Stein and coworkers used a range of granulocyte specific markers. ${ }^{8}$ The most effective for staining ReedSternberg cells were the reagents TU-9 and $3 \mathrm{C} 4 .^{9}$ The same group described a monoclonal antibody, $\mathrm{Ki}-1$, as a specific marker of Reed-Sternberg cells and a subset of small lymphocytes. ${ }^{10} 11$ This antibody, however, is effective only in fresh frozen tissue. Other workers found the granulocyte specific monoclonal antibody Leu-M1 to be an effective marker of Reed-Sternberg and Hodgkin cells. ${ }^{12-15}$

The presence of HLA-D region antigens on Reed-Sternberg cells has been shown in cell culture and frozen tissue. ${ }^{16-21}$ Until recently, however, no satisfactory marker of HLA-DR in fixed paraffin embedded tissue was available. The introduction of the monoclonal antibody TAL-IB5, ${ }^{22}$ which has been shown to be effective in acid formalin and Bouin's fixed paraffin embedded material, provides the opportunity to study HLA-DR in Hodgkin's tissue embedded in paraffin. 
In this study we compared the relative specificity of the two granulocyte specific monoclonal antibodies Leu-M1 and 3C4 in the diagnosis and differential diagnosis of Hodgkin's disease. We similarly aimed to assess the value of the monoclonal antibody to HLA-DR (TAL-IB5).

\section{Material and methods}

\section{SOURCE OF TISSUE}

Formalin fixed, acid formalin fixed ( $2 \%$ acetic acid in $4 \%$ formalin), and Bouin's fixed paraffin embedded tissue was taken from the surgical pathology files at this hospital. Four cases of lymphocyte predominant Hodgkin's disease, 14 of mixed cellularity Hodgkin's disease, 12 of nodular sclerosing Hodgkin's disease, and two of lymphocyte depleted Hodgkin's disease were studied. Twenty five cases of non-Hodgkin's lymphoma were similarly examined. Each of the cases of non-Hodgkin's lymphoma was selected for the presence of multinucleated giant cells resembling Reed-Sternberg cells. Full characterisation of these non-Hodgkin's lymphomas had previously been undertaken on frozen tissue using monoclonal antibodies.

\section{MONOCLONAL ANTIBODIES}

TAL-IB5, ${ }^{22}$ an IgGl monoclonal antibody to the HLA-D region antigen, was obtained from the Imperial Cancer Research Fund, Lincoln's Inn Fields, London. $3 \mathrm{C} 4,{ }^{23}$ a monoclonal antibody specific to the cells of late granulopoiesis, was a generous gift from Professor $\mathrm{H}$ Stein, University of Berlin. Leu-M1, ${ }^{24}$ a monoclonal antibody to cells of granulocyte lineage, was obtained from Becton, Dickinson Laboratory Systems, Laboratory Impex Ltd, Twickenham.

\section{IMMUNOPEROXIDASE REACTION}

Paraffin sections were cut at 3-4 $\mu \mathrm{m}$. These were dried at room temperature followed by $12-18$ hours at $56^{\circ} \mathrm{C}$. The sections were then deparaffinised and taken to industrial methylated spirit. Endogenous peroxidase was inhibited using freshly prepared minutes. Trypsinisation was then performed where needed (Table 1). The sections were washed in Tris
Table 1 Monoclonal antibodies used in this study

\begin{tabular}{lll}
\hline $\begin{array}{l}\text { Monoclonal } \\
\text { antibody }\end{array}$ & Dilution & Trypsinisation \\
\hline Leu-M1 & $1 / 1000-1 / 500$ & $5-20$ minutes* \\
3C4 & $1 / 4$ & $5-20$ minutes* \\
TAL-IB5 & Neat supernatant & None \\
\hline
\end{tabular}

*No trypsinisation was necessary in acid formalin or Bouin's fixed material.

buffered saline at $\mathrm{pH} \mathbf{7 . 6}$ for five minutes. Primary antibody was then applied at the appropriate working dilution (Table 1) for 60 minutes. The slides were washed, and peroxidase labelled rabbit antimouse serum (Dako), optimally diluted, was applied for 30 minutes. A further wash in Tris buffered saline was followed by the application of freshly prepared diaminobenzidine for 10 minutes. The slides were then washed and counterstained with Mayer's haematoxylin. In each case a control without application of primary antibody was performed.

\section{Results}

\section{HODGKIN'S DISEASE}

Table 2 summarises the immunocytochemical staining results. Both of the antigranulocyte antibodies produced a characteristic staining pattern in the Reed-Sternberg cells (Fig. 1b). A pronounced paranuclear blush in the Golgi region was accompanied by membrane staining of variable intensity, which was far greater in the tissues fixed in acid formalin and Bouin's fixative. The granulocytes showed strong membrane staining with dense intracytoplasmic granules that often obscured the nucleus. The staining of granulocytes was useful as an internal control in all the cases studied. Occasionally, focal intracytoplasmic staining with granulocyte specific antibodies was noted in macrophages. These macrophages were present in areas heavily infiltrated by neutrophils, and it could be seen that the staining was due to phagocytosed neutrophil debris. In addition to the staining of paraffin sections, cryostat cut sections from five cases were stained with antigranulocyte antibodies. In each case

Table 2 Reactivity of antigranulocyte antibodies and anti HLA-DR with Reed-Sternberg cells in Hodgkin's disease

\begin{tabular}{|c|c|c|c|c|}
\hline \multirow[t]{2}{*}{ Staining results } & \multicolumn{4}{|l|}{ Histological subtype } \\
\hline & Lymphocyte predominant & Mixed cellularity & Nodular sclerosing & Lymphocyte depleted \\
\hline $\begin{array}{l}\text { Leu-M1+/3C4- } \\
\text { Leu-M1+/3C4+ } \\
\text { Leu-M1+/3C4 not done } \\
\text { Leu-M1-/3C4+ } \\
\text { Leu-M1-/3C4- } \\
\text { TAL-IB5+ } \\
\text { TAL-IB5- } \\
\text { Total cases }\end{array}$ & $\begin{array}{l}- \\
\frac{-}{3} \\
\frac{4}{4}\end{array}$ & $\begin{array}{r}1 \\
9 \\
2 \\
-2 \\
12 \\
2 \\
14\end{array}$ & $\begin{array}{r}\overline{10} \\
1 \\
1 \\
\overline{11} \\
1 \\
12\end{array}$ & $\begin{array}{l}\frac{2}{2} \\
\frac{2}{2}\end{array}$ \\
\hline
\end{tabular}




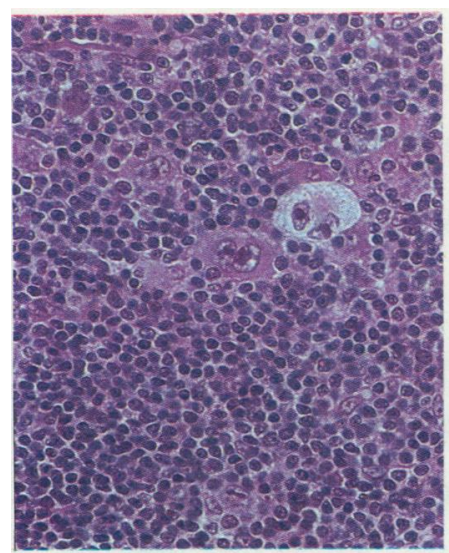

Fig. 1 (a)

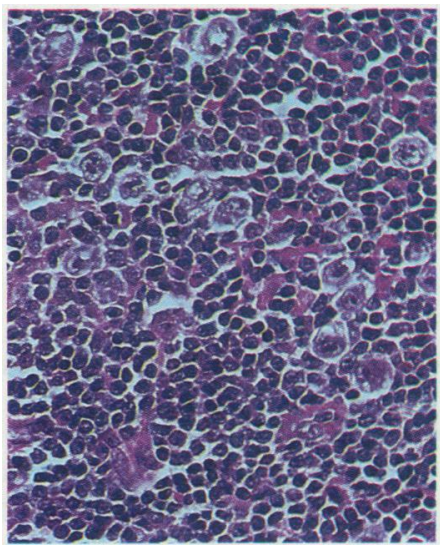

Fig. 2 (a)

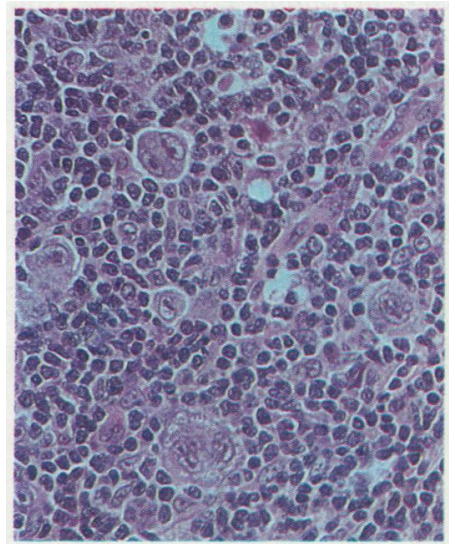

Fig. 3 (a)

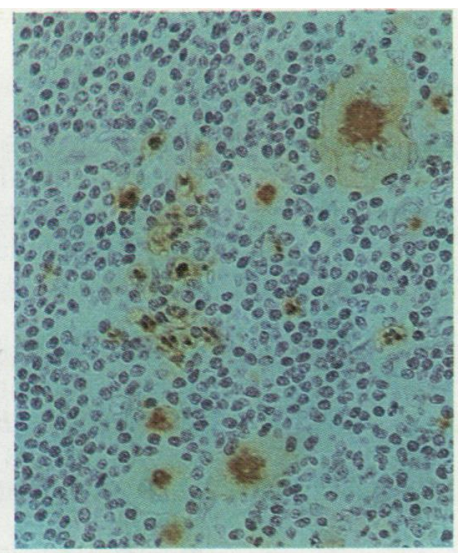

(b)

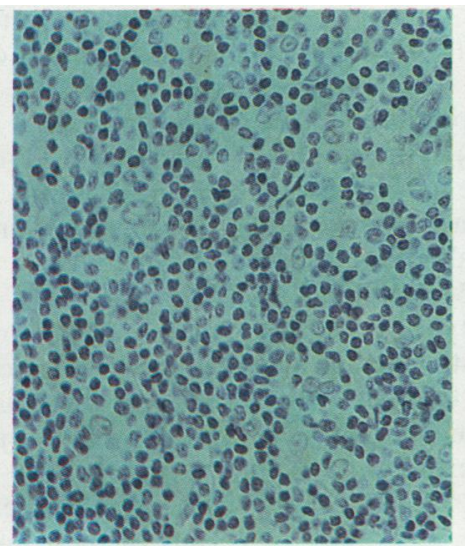

(b)

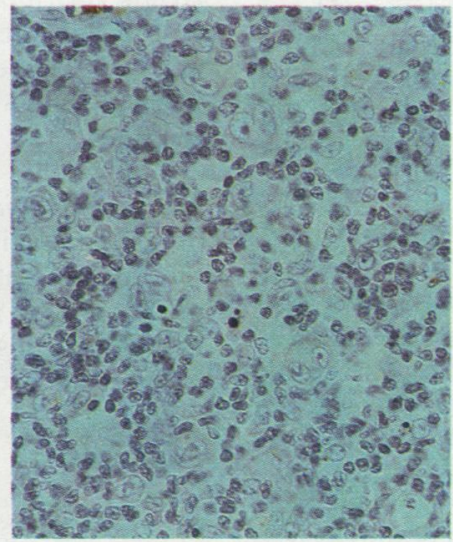

(b)

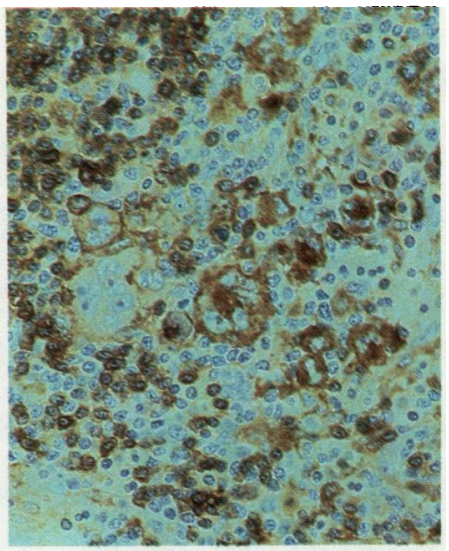

(c)

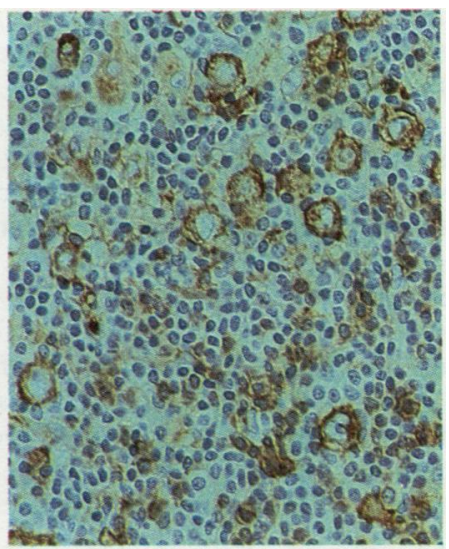

(c)

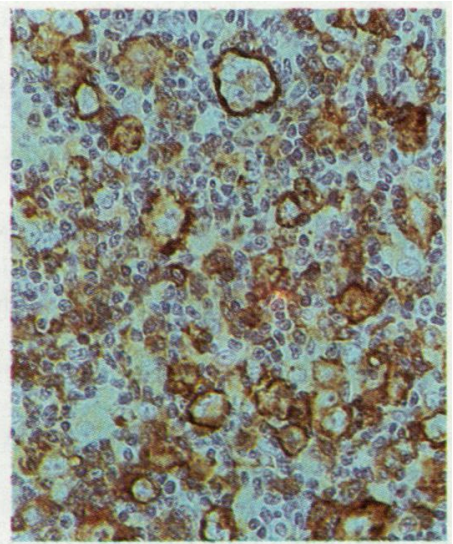

(c)

Fig. 1 Classical case of nodular sclerosing Hodgkin's disease. (a) Detail from centre of tumour nodule showing multinucleated Reed-Sternberg cells, lacunar cells, and mononuclear Hodgkin's cells. (b) Reed-Sternberg cells, lacunar cells, and Hodgkin's cells stained with monoclonal antibody Leu-M1. Note strong paranuclear blush in Golgi region and staining of background granulocytes. (c) Reed-Sternberg cells, lacunar cells, and Hodgkin's cells show strong expression of $H L A-D R$ with membrane and cytoplasmic staining.

Fig. 2 Lymphocyte and histiocyte predominant Hodgkin's disease. (a) Polylobated "Reed-Sternberg" (L and H) cells and Hodgkin's cells are seen in centre of lymphoid nodule. (b) $L$ and $H$ cells do not stain with Leu-M1. (c) $L$ and $H$ and Hodgkin's cells strongly express $H L A-D R$. Small background $B$ cells are also staining.

Fig. 3 Pleomorphic B cell lymphoma. (a) Many multinucleated tumour cells resembling Reed-Sternberg cells are seen. Background cells are centrocytes and centroblasts. (b) None of tumour giant cells stains with Leu-M1. Positive granulocyte is seen in one corner of field. (c) Tumour stained with TAL-IB5 showing strong membrane and cytoplasmic staining in giant cells. Smaller background lymphocytes also express $H L A-D R$. 
Table 3 Reactivity of antigranulocyte antibodies and anti $H L A-D R$ in non-Hodgkin's lymphomas

\begin{tabular}{|c|c|c|c|}
\hline \multirow{2}{*}{$\begin{array}{l}\text { Non-Hodgkin lymphomas } \\
\text { Histological type }\end{array}$} & \multicolumn{3}{|c|}{ Staining with: } \\
\hline & Leu-M1 & $3 C 4$ & $T A L-I B 5$ \\
\hline $\begin{array}{l}\text { Pleomorphic } \mathrm{T} \text { cell lymphoma } \\
(\mathrm{n}=7)\end{array}$ & $-(7)$ & $-(6 / 6)$ & $+(4)$ \\
\hline $\mathrm{T}$ Immunoblastic lymphoma & $-(1)$ & $-(1)$ & $+(1)$ \\
\hline $\begin{array}{l}\text { Mycosis fungoides }(n=6) \\
\text { Histiocytic lymphoma }\end{array}$ & $\begin{array}{l}+(2)^{*} \\
-(2)\end{array}$ & $\begin{array}{l}+(2)^{*} \\
-(2)\end{array}$ & $\begin{array}{l}-(6) \\
+(2)\end{array}$ \\
\hline $\begin{array}{l}\text { Malignant histiocytosis of } \\
\text { the intestine }(n=4)\end{array}$ & $-(4)$ & $-(3 / 3)$ & $+(4)$ \\
\hline Pleomorphic B cell & $-(4)$ & $-(4)$ & $+(4)$ \\
\hline B Immunoblastic lymphoma & $-(1)$ & $-(1)$ & $+(1)$ \\
\hline
\end{tabular}

*Fine dot positivity.

the staining pattern was identical with that seen in the paraffin sections.

TAL-IB5 gave granular intracytoplasmic staining in the Reed-Sternberg cells (Fig. 1c). This granular staining was often concentrated close to the nucleus. Granular cytoplasmic staining in macrophages and membrane staining in B cells was also noted. The intensity of staining with TAL-IB5 depended on several factors. The first was the type of fixative used. $^{21}$ TAL-IB5 staining was far stronger in acid formalin and Bouin's fixed tissue than in tissues fixed in unbuffered formol saline. Secondly, tissues that had been fixed for prolonged periods were also poorly stained by this antibody.

\section{LYMPHOCYTE PREDOMINANT HODGKIN'S DISEASE}

The four cases of lymphocyte predominant Hodgkin's disease were of the $\mathrm{L}$ and $\mathrm{H}$ nodular subtype. In all cases the antigranulocyte antibodies failed to stain the Reed-Sternberg and $\mathrm{L}$ and $\mathrm{H}$ cells (Fig. 2b). By contrast, HLA-DR was strongly expressed in these cells (Fig. 2c).

\section{MIXED CELLULARITY HODGKIN'S DISEASE}

The Reed-Sternberg cells in nine cases of mixed cellularity Hodgkin's disease stained with both antigranulocyte antibodies. Notably, one case marked only with Leu-M1 and two cases were consistently negative with both antibodies, even in cryostat cut sections. The expression of HLA-DR in these cases varied depending on fixation. Twelve cases gave positive staining with TAL-IB5. The negative cases had been fixed for a prolonged period in unbuffered formol saline.

NODULAR SCLEROSING HODGKIN'S DISEASE Reed-Sternberg cells in 11 of 12 cases of nodular sclerosing Hodgkin's disease stained with both antigranulocyte antibodies (Fig. 1b). One case stained only with the antibody 3C4. Expression of HLA-DR was present in 10 cases (Fig. 1c). Those that were negative had been adversely fixed.
LYMPHOCYTE DEPLETED HODGKIN'S DISEASE In two cases of lymphocyte depleted Hodgkin's disease the Reed-Sternberg cells stained with the antigranulocyte markers. HLA-DR was present in both cases.

\section{NON-HODGKIN'S LYMPHOMAS}

Table 3 summarises the immunocytochemical staining results. $B$ cell lymphomas Four cases of pleomorphic B cell lymphoma (Fig. 3a) and one case of $\mathbf{B}$ immunoblastic lymphoma were consistently negative with the antigranulocyte antibodies (Fig. 3b). Granular intracytoplasmic HLA-DR was consistently found in the giant cells (Fig. 3c). Membrane staining was present in most large cells as well as in the smaller B cells.

Pleomorphic T-cell lymphomas Seven cases of peripheral $T$-cell lymphoma were negative for Leu-M1 and 3C4. Expression of HLA-DR was present in four cases with large activated blast and giant cells.

Mycosis fungoides Two out of six cases of the tumour stage of mycosis fungoides showed fine dot like positivity in large blastic and smaller convoluted cells with the antigranulocyte antibodies. This pattern was finer and quite distinct from that seen in Hodgkin's disease. HLA-DR could not be shown in any of these cases.

Histiocytic (monocyte-macrophage) lymphoma Both cases of histiocytic lymphoma were negative for the antigranulocyte antibodies. Granular intracytoplasmic HLA-DR was strongly expressed in both cases.

Malignant histiocytosis of the intestine All four cases of malignant histiocytosis of the intestine were negative for the antigranulocyte antibodies. In one case phagocytosed neutrophils were stained within the neoplastic cells. HLA-DR was expressed in all the cases considered.

\section{Discussion}

In recent years several monoclonal antibodies have been shown to be effective in staining the ReedSternberg cells of Hodgkin's disease. The monoclonal antibody $\mathrm{Ki}-1$ was raised to a Hodgkin's derived cell line. ${ }^{10}$ It was regarded as specific for Reed-Sternberg cells and a subpopulation of small lymphoid cells. The antibody, however, is effective only in cryostat cut sections. Subsequent studies showed that the $\mathrm{Ki}-1$ antigen is expressed in various reactive and neoplastic conditions. ${ }^{25}{ }^{26}$ Mitogen acti- 
vated $\mathrm{T}^{25}$ and $\mathrm{B}$ cells, large cell lymphomas of $\mathrm{B}, \mathrm{T}$, and "null" cell types, and the cells of lymphomatoid papulosis are now known to be $\mathrm{Ki}-1$ positive. In questionable cases of Hodgkin's disease, therefore, the monoclonal antibody $\mathrm{Ki}-1$ can no longer be regarded as a reliable diagnostic aid.

Several antibodies raised to myeloid differentiation antigens seem to recognise determinants on Reed-Sternberg cells. ${ }^{8}{ }^{12}$ Their major advantage over $\mathrm{Ki}-1$ in routine diagnosis is their reactivity in both frozen and paraffin embedded tissues. Stein et al used a panel of four such antibodies. ${ }^{8}$ The most effective were the reagents TU9 and $3 \mathrm{C} 4$. In their series all cases of nodular sclerosing Hodgkin's disease, 24 of 26 cases of mixed cellularity, and 11 of 14 cases of lymphocyte depleted Hodgkin's disease marked with these antibodies. Notably, eight of 21 cases of lymphocyte predominant Hodgkin's disease also marked with these antibodies. This finding has not been reproduced subsequently using other antigranulocyte reagents. ${ }^{12} 14$ is Although 3C4 stains granulocytes and Reed-Sternberg cells, wide ranging reactivity with epithelial tissues has also been noted ${ }^{23}$ In this respect this antibody resembles Leu-M1. ${ }^{12}$ Several groups have used the Leu-M1 antigranulocyte marker. ${ }^{12-15}$ It stains immature and mature myeloid cells by immunoperoxidase and, by immunofluorescence, mitogen activated $T$ helper and, to a lesser degree, $\mathrm{T}$ suppressor cells. ${ }^{24} \mathrm{Hsu}$ and Jaffe found that Reed-Sternberg cells expressed this antigen in 20 cases of Hodgkin's disease of all subtypes. ${ }^{12}$ The only exceptions were two cases of lymphocyte predominant Hodgkin's disease in their series, which were negative with this antibody. In addition, 27 cases of $B$ and $T$ cell lymphomas were examined and found to be negative for Leu-M1. The authors did not comment, however, on the presence of giant cells like Reed-Sternberg cells in these cases. Pinkus and Said found that Reed-Sternberg cells in 69 cases of Hodgkin's disease expressed this antigen while four cases of lymphocyte predominant Hodgkin's disease were uniformly negative. ${ }^{15}$ In a series of 11 cases of nodular sclerosing and mixed cellularity Hodgkin's disease, however, Forni et al were able to stain only three cases with Leu-M1. ${ }^{13}$

In this study we found the antigranulocyte antibodies Leu-M1 and 3C4 to have similar specificity for the Reed-Sternberg cells of Hodgkin's disease. The intensity of staining with each of these antibodies varied. Variation in staining was also noted with the type of fixation used. Those cases fixed in acid formalin or Bouin's fixative gave far stronger staining of Reed-Sternberg cells compared with cases fixed in unbuffered formol saline. In addition, in two cases Reed-Sternberg cells marked with only one of the antibodies. It would seem, therefore, that
Leu-M1 and 3C4 are closely related but not identical antibodies.

HLA-DR staining of Reed-Sternberg cells using TAL-IB5 was particularly susceptible to the type of fixation. Those cases fixed in acid formalin or Bouin's fixative consistently gave strong staining. Tissues fixed in unbuffered formol saline gave variable results as did tissues fixed for prolonged periods.

The absence of staining with antigranulocyte antibodies in cases of lymphocyte predominant Hodgkin's disease agreed with the findings of most other groups. ${ }^{121415}$ In constrast to the findings of Stein et $a l,{ }^{9}$ we were unable to stain the neoplastic cells in $\mathrm{L}$ and $\mathrm{H}$ Hodgkin's disease using $3 \mathrm{C4}$. In addition, the polylobated $L$ and $H$ cells showed strong expression of HLA-DR. This finding, together with staining of the $L$ and $H$ cells with a pan $B$ reagent in one case with frozen tissue, further reinforces the view that $\mathrm{L}$ and $\mathrm{H}$ predominant Hodgkin's disease has a separate histogenesis from the other histological subtypes.

Two cases of mixed cellularity Hodgkin's disease were consistently negative with both of the antigranulocyte antibodies both in paraffin embedded and cryostat cut tissue. These cases had classical morphology, and further immunocytochemistry on paraffin and frozen sections was entirely consistent with the diagnosis. ${ }^{21}$ Both cases occurred in men. In the first the patient was 25 years old and had been treated 12 years before his present relapse. The second patient was 13 years old and had relapsed while receiving treatment after diagnosis one year previously. The initial biopsy material in these cases was also negative with the antigranulocyte markers. The expression of granulocyte antigens may be of prognostic importance in Hodgkin's disease and merits further investigation.

Two cases of Hodgkin's disease in this study were initially diagnosed by mediastinoscopic lymph node biopsy. The tissue was crushed and showed pronounced traction artefact. In spite of this artefact large multinucleated cells stained with the antigranulocyte antibodies. Subsequent biopsies and staging procedures in each case confirmed the diagnosis of Hodgkin's disease. In crushed and otherwise non-diagnostic material the antigranulocyte markers can be of great value in diagnosing Hodgkin's disease, particularly when classical Reed-Sternberg cells cannot be definitely confirmed in routinely stained sections.

The presence of giant cells resembling ReedSternberg cells in both $\mathrm{B}^{6}$ and $\mathrm{T}$ cell ${ }^{45}$ lymphomas can present difficulties in distinguishing these conditions from Hodgkin's disease. We have clearly shown that in such cases the antigranulocyte anti- 
bodies Leu-M1 and 3C4 are useful discriminants.

In two cases of the tumour stage of mycosis fungoides positive staining could be shown in the small and medium sized lymphocytes. The distribution was cytoplasmic and dot like in both cases. The finding of positive staining in cutaneous $T$ cell tumours was not unexpected as activated $T$ helper cells express the Leu-M1 antigen by immunofluorescence. ${ }^{24}$ Recently, another group claimed to have stained $T$ cell lymphomas with Leu-M1.27 Apart from cutaneous tumours, this has not been our experience with this antibody. In spite of this finding, as long as the strict criteria for the staining of Reed-Sternberg cells are observed, there should be no confusion with the occasionally positive $\mathrm{T}$ cell tumour. An additional useful distinguishing feature in these cases was the lack of HLA-DR expression in the antigranulocyte positive $T$ cell lymphomas.

With the exception of the lymphocyte predominant subtype the antigranulocyte antibodies were of great value in diagnosing Hodgkin's disease. These antibodies have the advantages of tissue specificity and flexibility over $\mathrm{Ki}-1$. Our findings indicate that it is desirable to use more than one antigranulocyte antibody in cases of diagnostic difficulty. In those cases in which Reed-Sternberg cells fail to mark with either marker the diagnosis of Hodgkin's disease should be in doubt. In such instances strict morphological criteria should be applied and supportive immunocytochemistry should be undertaken before the disease is diagnosed.

We thank K Miller, S Cotterill, and Sharon Law for their excellent technical help.

This work was supported by a grant from the North East Thames Regional Health Authority.

\section{References}

' Lukes RJ, Tindle BH, Parker JW. Reed-Sternberg-like cells in infectious mononucleosis. Lancet 1969;ii:1003-4.

${ }^{2}$ Tindle BH, Parker JW, Lukes RJ. "Reed-Sternberg" cells in infectious mononucleosis? Am J Clin Pathol 1972;58:607-17.

${ }^{3}$ Strum SB, Park JK, Rappaport H. Observation of cells resembling Sternberg-Reed cells in conditions other than Hodgkin's disease. Cancer 1970;26:176-90.

4 Pinkus GS, Said JW, Hargreaves H. Malignant lymphoma, T-cell type. A distinct morphologic variant with large multilobulated nuclei, with a report of four cases. Am J Clin Pathol 1979; 72: 540-50.

${ }^{5}$ Weinberg DS, Pinkus GS. Non-Hodgkin's lymphoma of large multilobulated cell type. A clinicopathologic study of ten cases. Am J Clin Pathol 1981;76:190-6.

- Stein H, Lennert K, Feller AC, Mason DY. Immunohistological analysis of human lymphoma: correlation of histological and immunological categories. In: Klein G, Weinhouse S, eds. Advances in cancer research. New York: Academic Press, 1984: 106.

' Wright DH, Isaacson PG. Biopsy pathology of the lymphoreticular system. London: Chapman and Hall, 1983:278-84.

${ }^{8}$ Stein H, Uchañska-Ziegler B, Gerdes J, Ziegler A, Wernet P. Hodgkin and Sternberg-Reed cells contain antigens specific to late cells of granulopoiesis. Int J Cancer 1982;29:283-90.
' Stein H, Gerdes J, Schwab U, et al. Identification of Hodgkin and Sternberg-Reed cells as a unique cell type derived from a newly-detected small-cell population. Int J Cancer 1982; 30:445-59.

${ }^{10}$ Schwab U, Stein H, Gerdes J, et al. Production of a monoclonal antibody specific for Hodgkin and Sternberg-Reed cells of Hodgkin's disease and a subset of normal lymphoid cells. Nature 1982; 299:65-7.

"Stein H, Gerdes J, Kirchner H, Schaadt M, Diehl V. Hodgkin and Sternberg-Reed cell antigen(s) detected by an antiserum to a cell line (L428) derived from Hodgkin's disease. Int J Cancer 1981;28:425-9.

${ }^{12}$ Hsu S, Jaffe E. Leu-M1 and peanut agglutinin stain the neoplastic cells of Hodgkin's disease. Am J Clin Pathol 1984;82:2932.

${ }^{13}$ Forni M, Hofman FM, Parker JW, Lukes RJ, Taylor CR. B- and T-lymphocytes in Hodgkin's disease. An immunohistochemical study utilizing heterologous and monoclonal antibodies. Cancer 1985;55: 728-37.

14 Hsu S, Yang K, Jaffe ES. Phenotypic expression of Hodgkin's and Reed-Sternberg cells in Hodgkin's disease. Am J Pathol 1985; 118: 209-17.

is Pinkus GS, Said W. Hodgkin's disease, lymphocyte predominance type, nodular-a distinct entity? Am J Pathol 1985; 1:1-6.

${ }^{16}$ Kadin ME, Billing RJ. B lymphocyte antigens in the differential diagnosis of human neoplasia. Blood 1978;51:813-23.

${ }^{17}$ Poppema S, Bhan AK, Reinherz EL, Posner MR, Schlossman SF. In situ characterisation of cellular constituents in lymph nodes and spleens involved by Hodgkin's disease. Blood 1982;59:226-32.

${ }^{18}$ Borowitz MJ, Croker BP, Metzgar RS. Immunohistochemical analysis of the distribution of lymphocyte subpopulations in Hodgkin's disease. Cancer Treat Rep 1982;66:667-74.

${ }^{14}$ Stuart AE, Jackson E, Moris CS. The reaction of xenogeneic and monoclonal antisera with Reed-Sternberg cells. J Pathol 1982;137:129-38.

${ }^{20}$ Stuart AE, Volsen SG, Zola H. The reactivity of Reed-Sternberg cells with monoclonal antisera at thin section and ultrastructural levels. J Pathol 1983;141:71-82.

21 Dorreen MS, Habeshaw JA, Stansfeld AG, Wrigley PFM, Lister TA. Characteristics of Sternberg-Reed, and related cells in Hodgkin's disease: an immunohistological study. $\mathrm{Br} \mathrm{J}$ Cancer 1984;49:465-76.

${ }^{22}$ Epenetos A, Bobrow L, Adams T, Collins C, Isaacson P, Bodmer W. A monoclonal antibody that detects HLA-D region antigen in routinely fixed wax embedded sections of normal and neoplastic lymphoid tissues. J Clin Pathol 1985;38:12-7.

${ }^{23}$ Schienle H, Stein H, Müller-Ruchholtz W. Neutrophil granulocytic cell antigen defined by a monoclonal antibody-its distribution within normal haemic and non-haemic tissue. J Clin Pathol 1982;35:959-66.

24 Hanjan S, Kearney J, Cooper M. A monoclonal antibody (MMA) that identifies a differentiation antigen on human myelomonocytic cells. Clin Immunol Immunopathol 1982; 23: 172-88.

${ }^{25}$ Andreesen R, Osterholz J, Löhr G, Bross K. A Hodgkin cellspecific antigen is expressed on a subset of auto- and alloactivated T (helper) lymphoblasts. Blood 1984;63:1299-302.

${ }^{26}$ Stein H, Mason DY, Gerdes J, et al. The expression of the Hodgkin's disease associated antigen $\mathrm{Ki}-1$ in reactive and neoplastic lymphoid tissue. Evidence that Reed-Sternberg cells and histiocytic malignancies are derived from activated lymphoid cells. Blood. (in press).

${ }^{27}$ Schnitzer B, Hyder D. Leu-M1 monoclonal antibody staining of Reed-Sternberg cells. Lancet 1985; i: 757.

Requests for reprints to: Professor PG Isaacson, Department of Histopathology, School of Medicine, University College London, University Street, London WC1E 6JJ, England. 